\title{
The role of material engineering within the concept of an integrated water resources management
}

\author{
Raphael Breiner $^{1} \cdot$ Harald S. Müller ${ }^{1}$
}

Received: 15 January 2016/ Accepted: 12 May 2016/Published online: 28 May 2016

(c) The Author(s) 2016. This article is published with open access at Springerlink.com

\begin{abstract}
By means of a case study, the successful implementation of a rheologically optimised cement-based mortar for the construction as well as for the rehabilitation of rain water cisterns is presented in this paper. The material was developed within the scope of a GermanIndonesian joint project ["Integrated Water Resources Management" (IWRM)], funded by the German Federal Ministry of Education and Research. Comprehensive rheological investigations are presented which provide the database for the optimization of the mortar with regard to its intended range of application. For the selection of the source materials, special emphasis was placed on the ready availability at low cost. The rheological properties of the fresh mortar allow an easy workability by hand while the hardened mortar shows a durable and tight appearance at the same time. The developed material can be used as a coating for walls, floors and ceilings of cisterns, for the local rehabilitation of damaged areas only or even as a construction material for complete new cisterns. The future multiplication of the IWRM project results within the region was assured by a local capacity development when the presented material concept was applied in practise in Indonesia for the construction of sustainable rain water cisterns in Gunung Kidul.
\end{abstract}

Keywords Cement - Concrete - Concrete technology · Rheology · Additives · Cisterns · Rehabilitation

Raphael Breiner

raphael.breiner@kit.edu

1 Institute of Concrete Structures and Building Materials (IMB), Karlsruhe Institute of Technology (KIT), Karlsruhe, Germany

\section{Introduction}

Within the scope of a German-Indonesian joint project, funded by the German Federal Ministry of Education and Research (BMBF), a hydropower plant with an underground concrete barrage (see Fig. 1) was initialized, designed and built during the years of 2002-2008. Especially during dry seasons it provides an urgently required water supply for the karst region Gunung Sewu in central Java, Indonesia (Müller et al. 2008; Nestmann et al. 2012). The basic conception and the predesign of the concrete barrage were accomplished by the Institute of Concrete Structures and Building Materials (IMB), Karlsruhe Institute of Technology (KIT).

Within the presented German-Indonesian follow-up project funded also by BMBF, the hydropower plant was embedded into the frame of an "Integrated Water Resources Management" (IWRM), which couples all aspects of water supply, distribution, usage and treatment in an overall concept (Oberle et al. 2005). The Institute of Concrete Structures and Building Materials (IMB, Subproject 5) of the Karlsruhe Institute of Technology (KIT) was involved in the work packages (WP) two (water extraction), three (water distribution), four (wastewater) and six (capacity development). The focus was set on the development and provision of appropriate technical engineering concepts to ensure permanently watertight and functional hydraulic constructions which resulted in the following main objectives:

- Development and optimization of injection materials for the karst rock around the underground hydro-power driven water supply system in Bribin cave.

- Development and pre-design of concrete structures for a field model of hydropower driven water supply

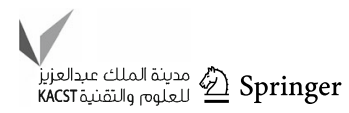




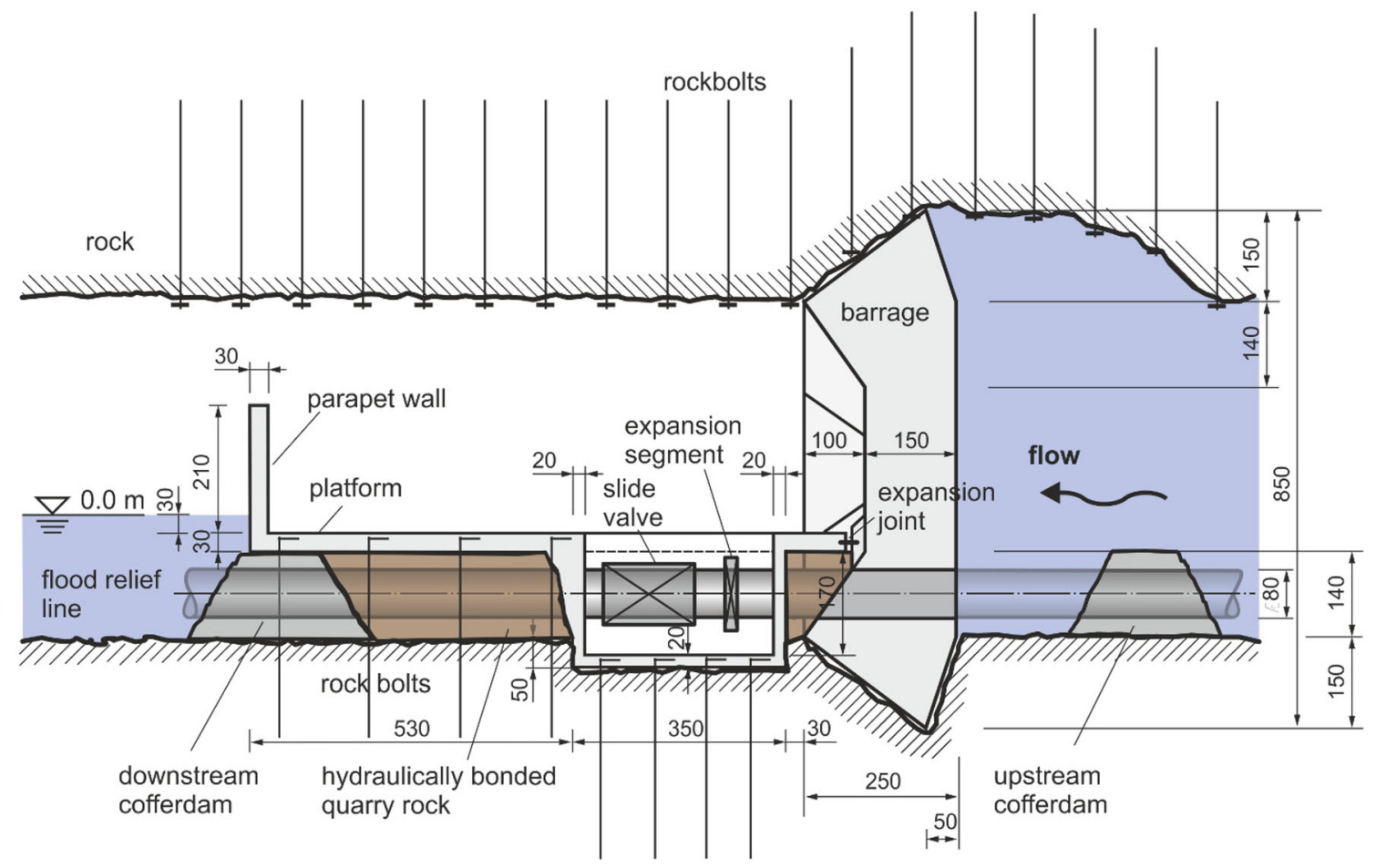

Fig. 1 Sketch of the structure of the hydropower plant (longitudinal section, without hydraulic components) with the functional elements cofferdam, flood relief line, barrage and platform with valve chamber (Bohner et al. 2009)

system with wood-stave pipeline; see (Nestmann et al. 2015).

- Development of rehabilitation measures for the Bribin water distribution network.

One aspect was to rehabilitate and enlarge the existing water storage and distribution system in the project region to handle the additional water supplied by the new hydropower plant Bribin. Consequently, Subproject 5 included amongst others the development and rheological optimization of an appropriate mortar for the rehabilitation or even reconstruction of sustainable rain water cisterns in the village of Pucanganom, which will be presented in this paper. The objective of the works described in the following was to minimise the water losses due to cracks and to guarantee the secure and durable long time operation of the cisterns consequently.

\section{Preliminary field study}

Pucanganom, located in the karst area of Gunung Sewu near the city of Wonosari, was chosen within the IWRMProject as a pilot village where the developed measures of the different subprojects are implemented in an integrated way to prove their applicability and to support a future multiplication in the region.
Initial contact was made to the public authorities in Pucanganom responsible for construction activities. They facilitated the detailed determination and evaluation of the current condition of existing cisterns with regard to their tightness, structural design, materials used as well as rehabilitation requirements.

During an earthquake in May 2006 (Walter et al. 2008) many domestic water cisterns were damaged or even completely destroyed. In the following years, new cisterns with a volume of $\sim 9 \mathrm{~m}^{3}$ were built by local village people who were trained within the scope of international and national aid programmes (e.g. UNICEF, Red Cross). Teams of two workmen were trained to build a cistern within 4 days supported by six unskilled workers. However, these programmes focused more on constructional aspects rather than on material optimization.

The present construction material for the cisterns in Pucanganom is a mortar with quite high cement content. Sand and cement are mixed together two parts by one and water is added until the desired workability is reached which corresponds to a water/cement-ratio on site of $\sim 0.45$. The mixing itself is done by hand in-situ (see Fig. 2),

No ingredients other than sand and cement are added to the mortar. In particular no commercially available concrete additives are used. The cement is an ordinary Portland cement (OPC) or a puzzolanic Portland cement (PPC), 


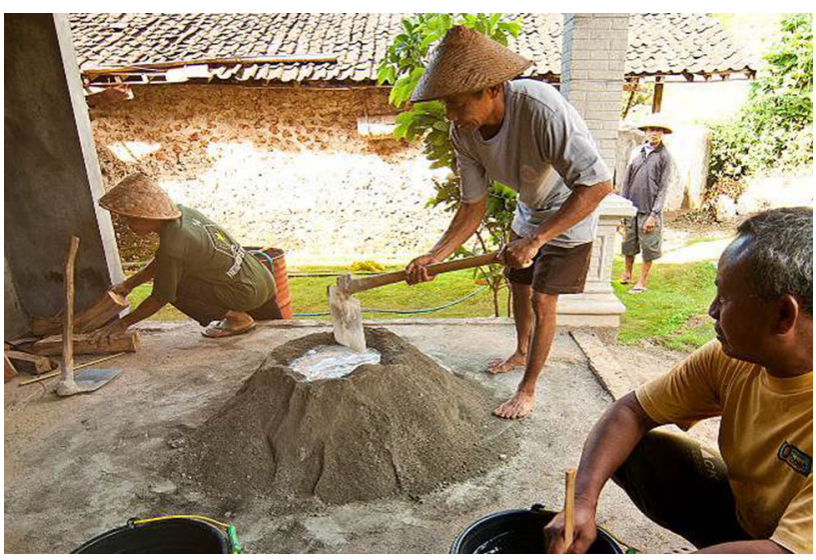

Fig. 2 Mixing of the mortar in-situ

depending on availability. The sand is raw volcanic sand with a squared shape and grain size diameters up to $4 \mathrm{~mm}$.

The construction always follows the same appropriate principle. On the first day, a base-course for the foundation of the water cistern is assembled which consists of raw and crude limestones assembled similar to prepacked concrete.

The aggregates generally have a medium diameter between 100 and $200 \mathrm{~mm}$ and show a very high porosity due to their karst origin. They mostly originate form karst limestone quarries near to the site or are even collected directly from the surrounding. On this base-course a round foundation is modelled with a simple mortar consisting of four parts of sand and one part of cement (see Fig. 3, top).

On the second day, the reinforcement cage of the water cistern is tied together with smooth reinforcement steel having a diameter of 6 and $8 \mathrm{~mm}$, respectively. The whole reinforcement cage is wrapped with a wire mesh fence (chicken wire) and a bamboo mat, which acts as formwork for the application of the mortar on the inner side of the cistern.

The reinforcement cage is put on the foundation, which has been treated before at the beginning of the third day with a screed on a layer of old cement bags to assure a decoupling of the construction in case of a future earthquake (see Fig. 3, top).

After all necessary pipe and drainage installations are made the inner mortar layer is applied by hand on the cistern walls (see Fig. 3, bottom). After the hardening of the inner mortar layer, the bamboo formwork is removed on the beginning of the fourth day. Consequently the outer mortar layer is applied (see Fig. 4, top). The mortar layer on the ceiling is made against a layer of old cement bags which are installed from inside the reinforcement cage (see Fig. 4, bottom).

During the construction works it became evident that from a technical and economical point of view, the controlling of the rheological behaviour of the mortar is the key factor to achieve the best possible imperviousness of
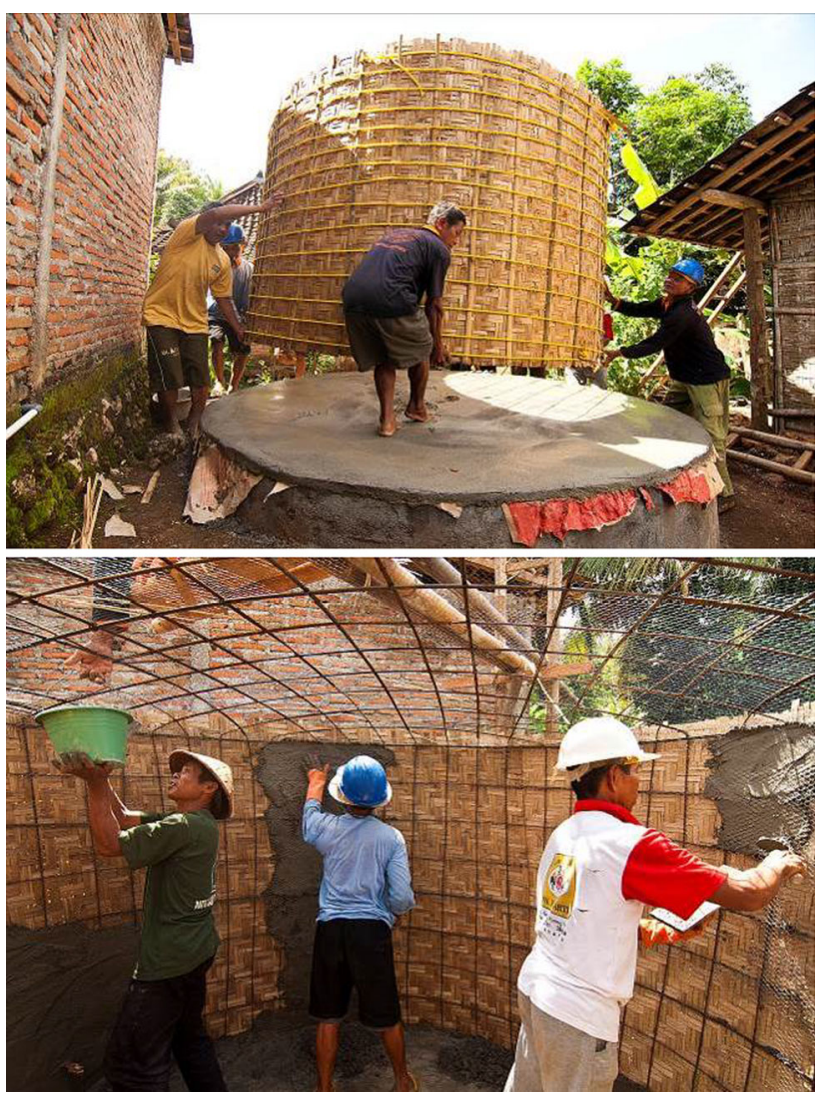

Fig. 3 Transport of the prefabricated reinforcement cage to the cistern foundation which has been treated with a screed on a decoupling layer of old cement bags before (top) and application of the inner mortar layer (bottom)

water cisterns. It would be desirable to have at one's disposal a practical guideline of how to compose the mortar according to its intended range of application.

\section{Materials}

Based on the experiences gained during the preliminary field study described above as well as a literature survey, the source materials for the investigation were selected and carefully characterised considering their usage as mortar ingredients.

The main restriction for planning and construction was to use only locally available source materials. Their selection and their properties are discussed shortly in the following.

\section{Cement}

Numerous cement plants exist in Indonesia being controlled by worldwide operating cement producing companies. However, in practise only Portland cements (OPC

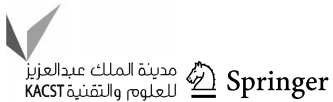



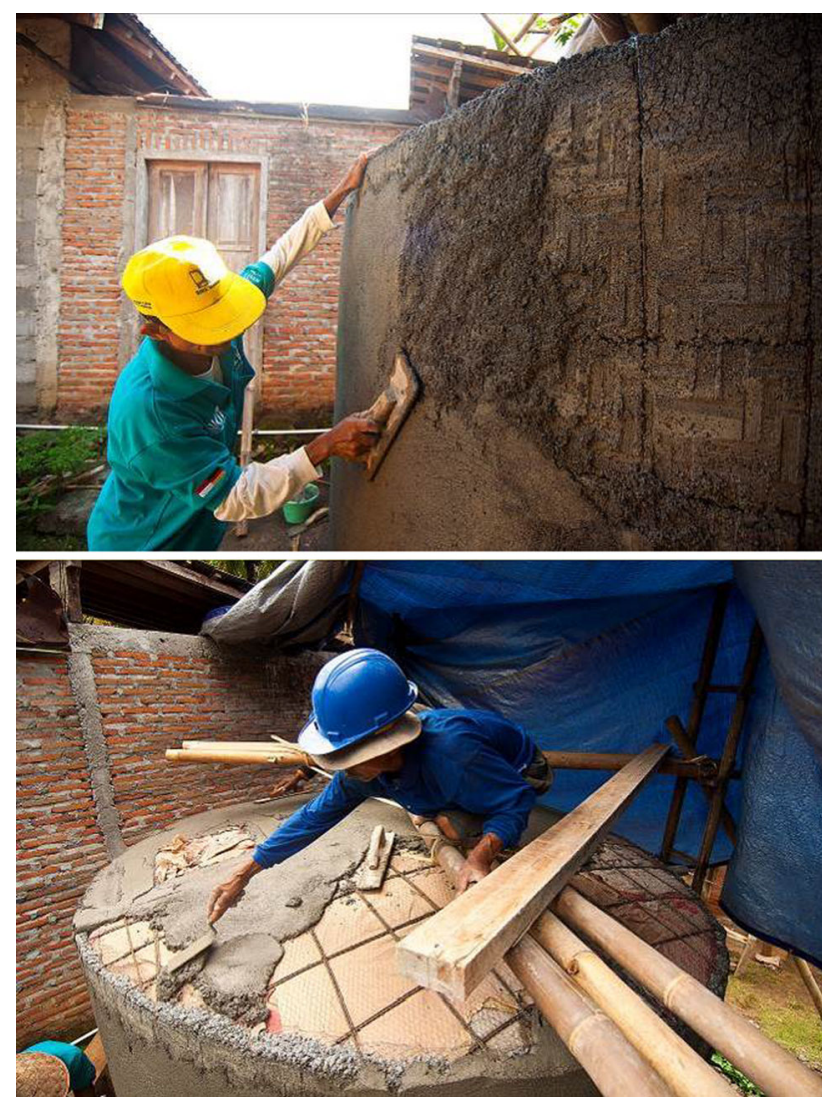

Fig. 4 Application of the outer mortar layer (top) and application of the mortar on the ceiling (bottom)

Type I) and so-called Portland puzzolanic cements (PPC) are used. Preliminary experiments and investigations at the IMB substantiated to favour an OPC Type I produced by the Gresik company for the mortar optimization in Pucanganom. It has a Blaine-value of $3690 \mathrm{~cm}^{2} / \mathrm{g}$ and a density of $3.09 \mathrm{~g} / \mathrm{cm}^{3}$. The cheaper PPC held a substantial amount of indissoluble components, had a lower grinding fineness and was consequently excluded.

\section{Sand}

During the exploration of numerous digging and excavation facilities for sand and gravel as well as concrete plants in the region of Yogyakarta, important information for the selection of concrete aggregates in Indonesia was gained. The sand used for construction measures in Yogyakarta and Gunung Sewu exclusively comes from the Merapi area. It can be described as raw volcanic sand with a comparatively high dry density of $3.17 \mathrm{~g} / \mathrm{cm}^{3}$.

\section{Additives and admixtures}

Superplasticizers (SP) were not intended to be used in the mortar mix to ensure its economic composition. However, the commercially available product SIKA ViscoCrete 1050 was investigated as a reference.

It is a universal and highly effective superplasticizer based on polycarboxylatether polymers especially developed for ready-mix concretes. It has a density of $1.06 \mathrm{~g} /$ $\mathrm{cm}^{3}$ and shows a long-lasting efficiency. It was examined to which extent the water/cement-ratio of the cement suspension could be lowered by replacing the superplasticizer-a comparatively expensive chemical product—by a low priced saccharose (local retail sugar).

Admixtures like fly ash do not exist in Indonesia or they are available as expensive import products only. Locally available ashes from the hillsides of the Merapi volcano and further a rice husk ash (Indonesian: abu sekam padi) were investigated but unfortunately did not show any hydraulic properties, which were necessary for a qualified use in the mortar mix.

With regard to the control of the sedimentation behaviour the clay mineral bentonite is used to stabilise cement suspensions by increasing the suspensions thixotropy. Furthermore, bentonite binds free water due to its stratification structure and thus prevents bleeding. Consequently a locally available bentonite mineral was examined. It could be identified by means of X-ray diffraction analysis as sodium-bentonite with a density of $2.71 \mathrm{~g} / \mathrm{cm}^{3}$. In addition its quantitative composition was determined together with the Institute of Mineralogy and Geochemistry (IMG) of the KIT using X-ray fluorescence analysis.

\section{Rheological investigations}

To determine the flow behaviour of the pure cement suspension phase of the mortar and to evaluate the influence of the different additives and admixtures rheological investigations were performed. A measuring system consisting of a high-end rheometer (Haake MARS) combined with a measuring cell especially developed for cement suspensions were used (see Fig. 5).

The measuring cell consists of a cylindrical vessel with an adjustable wall serration to account for different grain size diameters and to prevail a sliding of the cement suspension in the contact face to the wall. The cell filled with cement suspension is installed into the rheometer and defined shear stresses are consequently applied with a paddle-shaped rotor to determine the rheological properties.

The water/cement-ratio of the tested cement suspensions amounted in each case to 0.5. Measurements were performed 5, 15, 30 and 60 min after the addition of water. Table 1 summarises the mix compositions for the rheological investigations. 


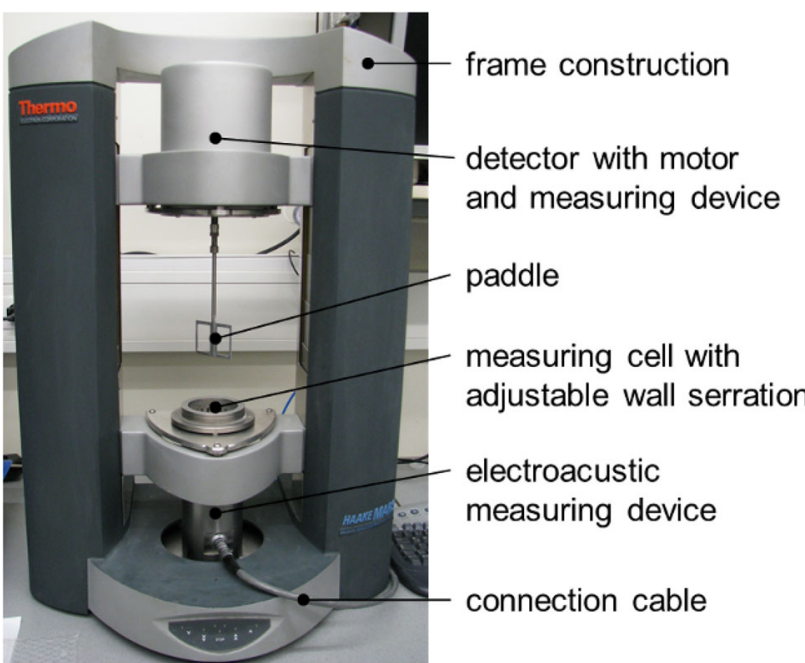

Fig. 5 Rheometer Haake Mars (Haist 2009)

Rheological measurements were carried out to evaluate the effectivity of sugar (sac.) to replace the tested superplasticizer (SP). For this purpose the cement suspensions were mixed with graded dosages of sugar and superplasticizer and consequently rheologically characterised. Measurements were performed 5, 15, 30 and 60 min after water was added to the dry cement at atmospheric pressure and a constant temperature of $20{ }^{\circ} \mathrm{C}$. In Fig. 6 the influence of sugar and superplasticizer on the flow behaviour of the cement suspension is illustrated over the whole shear rate range.

It can be clearly observed that yield stress and dynamic viscosity decrease with increasing sugar content. It should be noted that already a sugar content of $0.05 \%$ by mass of the cement leads to a significant drop of the flow curve similar to the addition of the superplasticizer by $0.2 \%$ by mass of the cement.

In addition, the influence of bentonite (ben.) and rice husk ash (rha.) on the flow behaviour were examined. For this purpose the cement suspensions were mixed with previously determined amounts of rice husk ash and bentonite and consequently rheologically characterised. Like

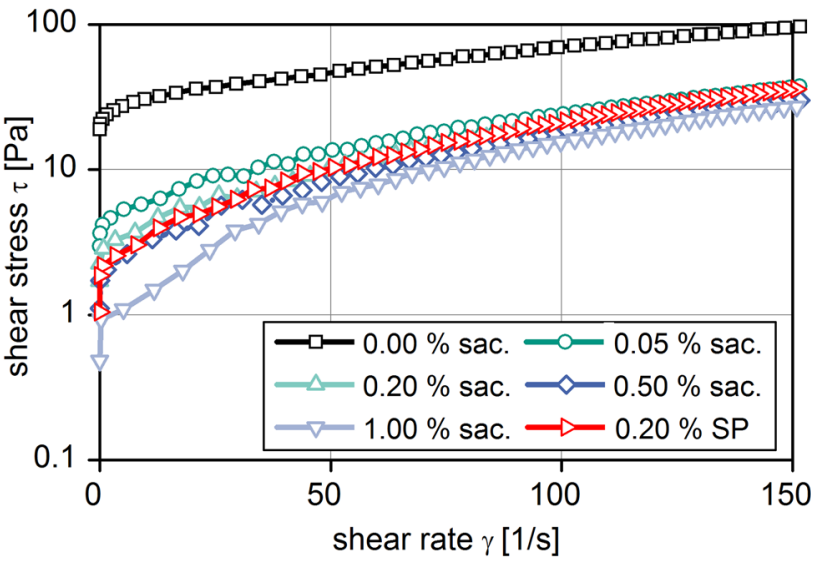

Fig. 6 Influence of sugar (sac.) and superplasticizer (SP) on the flow behaviour of the cement suspensions with a water/cement ratio of 0.5 and $15 \mathrm{~min}$ after addition of water at atmospheric pressure and a temperature of $20{ }^{\circ} \mathrm{C}$

before, measurements were performed 5, 15, 30 and 60 min after water was added to the dry cement at atmospheric pressure and a constant temperature of $20^{\circ} \mathrm{C}$. Figure 7 shows the change of the flow properties of the cement suspensions over the whole shear rate range depending on the respective addition.

The addition of bentonite to the pure cement suspension resulted in an increased yield stress and dynamic viscosity. When sugar was added, yield stress and viscosity dropped even below the values of the pure cement suspension. Further the addition of rice husk ash as a puzzolan to a sugared cement suspension reduced the effect of the sugar. However, yield stress and viscosity still were lower compared to a pure cement suspension. Figure 7 shows these experimental results $15 \mathrm{~min}$ after the addition of water.

\section{Fresh mortar experiments}

Following the investigation of the flow behaviour of the cement suspensions with the rheometer, the consistency of different mortar mixtures was examined with conventional

Table 1 Mix compositions for the rheological investigations

\begin{tabular}{lllll}
\hline$w / c(-)$ & $(\%$ by mass of cement $)$ & & \\
\cline { 2 - 5 } & Sugar & Superplasticizer & Bentonite & - \\
\hline 0.5 & 0.05 & - & - & - \\
0.5 & 0.20 & - & - & - \\
0.5 & 0.50 & - & - & - \\
0.5 & 1.00 & - & - & - \\
0.5 & - & 0.20 & 0.50 & - \\
0.5 & - & - & 0.50 & - \\
0.5 & 0.05 & - & - & 5.00 \\
0.5 & 0.05 & - & & \\
\hline
\end{tabular}




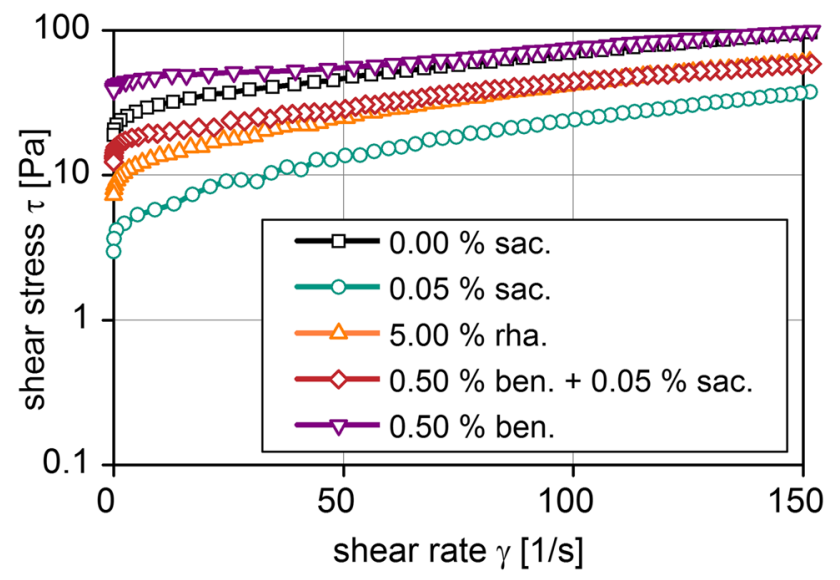

Fig. 7 Influence of sugar (sac.), rice husk ash (rha.) and bentonite (ben.) on the flow behaviour of the cement suspensions with a water/ cement ratio of 0.5 and 15 min after addition of water at atmospheric pressure and a temperature of $20^{\circ} \mathrm{C}$

methods and compared with the results of an industrial mixture for drinking water cisterns in Germany as well as with the Indonesian reference mixture.

After mixing of the mortars in a Hobart-mixer, the slump values of all mixtures were determined $5,15,30$ and $60 \mathrm{~min}$ after the addition of water to the dry ingredients according to DIN 1015-3 (2007). Furthermore, the flow behaviour of the mortar when applied to an inclined plane was evaluated with a so-called slip-test 10 and 40 min after water addition. The test setup was developed in 2002 for testing and optimisation of mortar workability [Institute of Concrete Structures and Building Materials (IMB), Department Building Materials 2002]. The individual steps and exemplary results for a stiff and a smooth mixture are illustrated in Fig. 8.

The mortar is applied with a thickness of $5 \mathrm{~mm}$ in a flat formwork with an edge length of $10 \mathrm{~cm}$. It is mounted with an angle of $75^{\circ}$ to the horizontal surface in a metal frame and positioned on a Hägermann-table to be stressed with 15 impacts. The maximum value of the mortar slip is taken as criteria for the application behaviour of the mortar in-situ.

In total 71 fresh mortar experiments were performed. Initially the water/cement-ratio and the sand/cement-ratio were varied as main parameters of the mortar composition to figure out the overall limits of workability. Afterwards the effects of the addition of different amounts of commercial superplasticizer and stabiliser as well as local sugar, bentonite, cassava flour and rice husk ash were studied. A description of all results and their detailed analysis can be found in Heid (2012).

The best results were gained with a mixture comprising a lowered water/cement-ratio of 0.4 , a higher sand/cementratio of 2.5 and the addition of both saccharose with a content of $0.05 \%$ by mass of the cement and bentonite with a content of $0.5 \%$ by mass of the cement. Figure 9 illustrates the behaviour of the slump value over the processing period.

The new mortar mixture shows a good workability reaching the aimed slump range during the whole processing period. Compared to the industrial reference mixture (Pagel TW 20) and the common Indonesian mixture, the slump values tend to be slightly higher which favours an easier workability. However, its applicability, i.e., its ability to be applied on vertical surfaces and even on ceilings was not endangered at any time. This can also be seen in Fig. 10, where the rheological behaviour of the new and the common mixture is compared.

The new mixture has a similar yield stress of about $19 \mathrm{~Pa}$ compared to $17 \mathrm{~Pa}$ of the common mixture. Furthermore, its viscosity is somewhat lower due to the addition of sugar which favours the workability. The applicability ("stickiness") was still similar due to the addition of bentonite which stabilises the mixture. The material composition and its main rheological properties are summarised in Table 2.

\section{Hardened mortar properties}

Based on the results from the rheological investigations of cement suspensions and the fresh mortar experiments, the mechanical properties were finally determined on hardened mortar specimens.

Prismatic specimens with a length of $160 \mathrm{~mm}$ and a square cross-section of $40 \times 40 \mathrm{~mm}$ were produced according to DIN EN 1015-11 (2007). The prisms were wrapped in foil and stored for 1 week under humid jute. Until the time of testing after 28 days, the prisms were stored unwrapped in a climate chamber at a temperature of $20{ }^{\circ} \mathrm{C}$ and a relative humidity of $65 \%$. Table 3 summarises the mix compositions for the investigations of the hardened mortar properties.

The compressive strength and the flexural tensile strength of the hardened mortar were determined according to DIN EN 1015-11 (2007). Furthermore, the pore volume and the pore size distribution of the cement stone were given by mercury intrusion porosimetry according to DIN 66133 (1993). After 28 days also the water absorption of the mortar specimens under atmospheric pressure and under a pressure of 150 bar were determined according to DIN 52009 (2006). Finally, the density according to DIN EN 12390-7 (2009) and the total porosity according to DIN 52102 (2006) were examined. The results of the investigations on the hardened mortars are presented in Table 4 .

The results of the investigations on the hardened mortar specimens showed both a high compressive strength and a high flexural tensile strength for all mixtures. Due to the 
Fig. 8 Setup of the slip-test: formwork filling with mortar (top and middle left), formwork on the Hägermann-table (top right) and exemplary results for a stiff (bottom left) and a smooth (bottom right) mixture [Institute of Concrete Structures and Building Materials (IMB), Department Building Materials 2002]
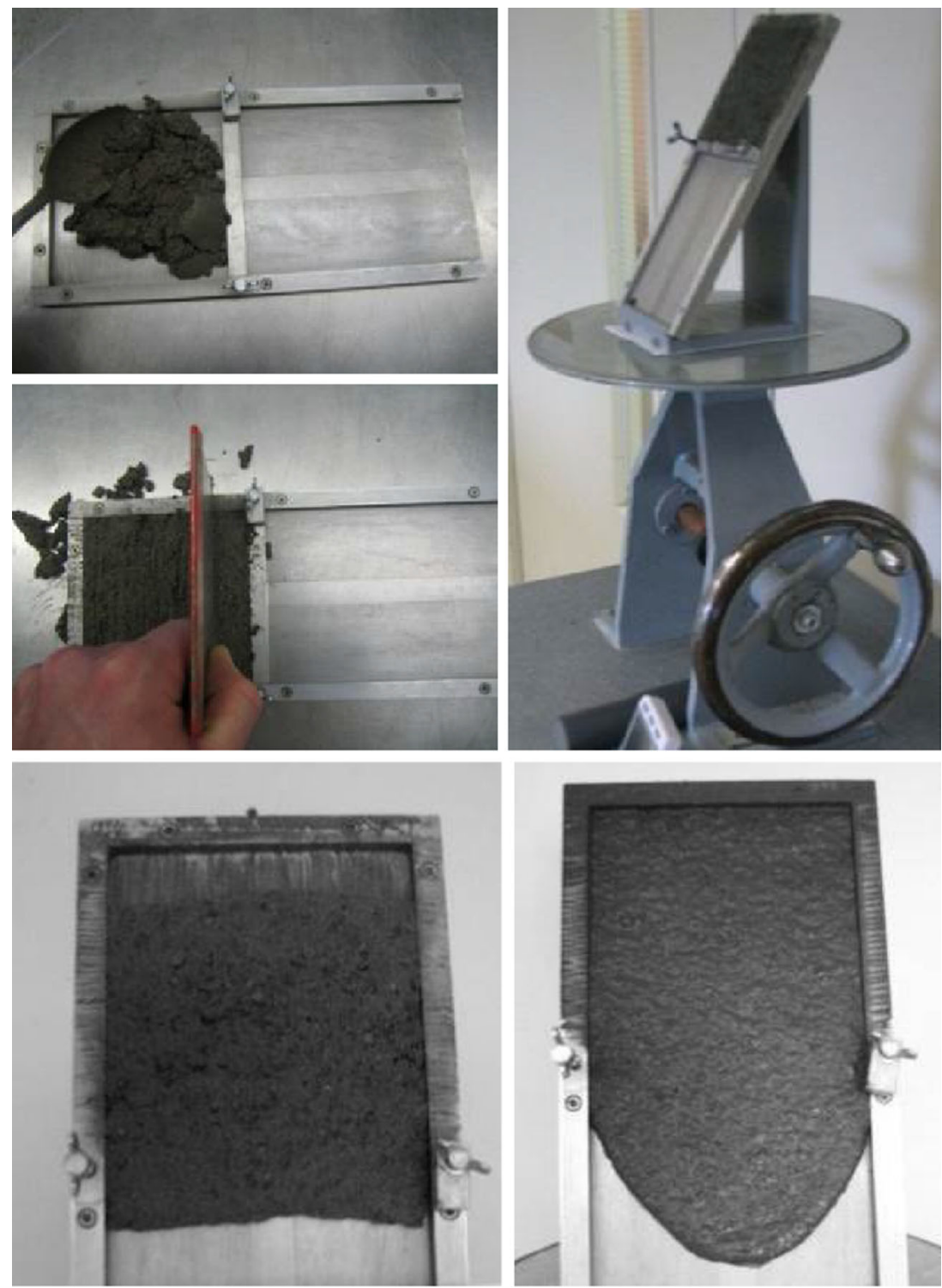

high cement content, the common Indonesian mixture Ref 2 showed the highest strength values.

The commercially available mortar Ref 1 showed the lowest strength value. However, no detailed mixture composition was available to further evaluate this behaviour. The low water/cement-ratio of mixtures $M 1, M 2$ and M3 of 0.4 resulted in a high compressive strength as expected. The inclusion of sugar did not seem to affect the compressive strength negatively. Also the effect of bentonite was still in the scattering band. The reduction of the water/cement-ratio aimed to decrease the porosity of the mortar as low as possible to guarantee a high durability. A German regulation (DVGW W 300 DVGW Arbeitsblatt W 2005) suggests for cistern mortars a HG-porosity lower than $12 \%$ by volume. This was almost reached by all mixtures $M 1-M 3$ (see Table 4) which showed a mean porosity of $13.4 \%$. The mixture $M 2$ with the addition of sugar had a slightly higher porosity than $M 1$. However, the increase was still in the scattering band and an effect of the sugar on the porosity was, therefore, excluded. All mixtures showed a favourable pore size distribution with a little percentage of capillary pores (see Fig. 11).

Compared to the requirement of porosity lower than $12 \%$ according to DVGW W 300 (DVGW Arbeitsblatt W 2005), the porosity values of mixtures $M 1-M 3$ are acceptable, while the Indonesian reference mixture Ref 2 had a higher porosity of $16.3 \%$ due to its higher water/ cement-ratio. Surprisingly, the industrial reference mixture Ref 1 showed the highest porosity of $17.3 \%$ and in addition the highest share of capillary pores (see Fig. 11). The determination of the water absorption under atmospheric pressure and under a pressure of 150 bar produced similar 


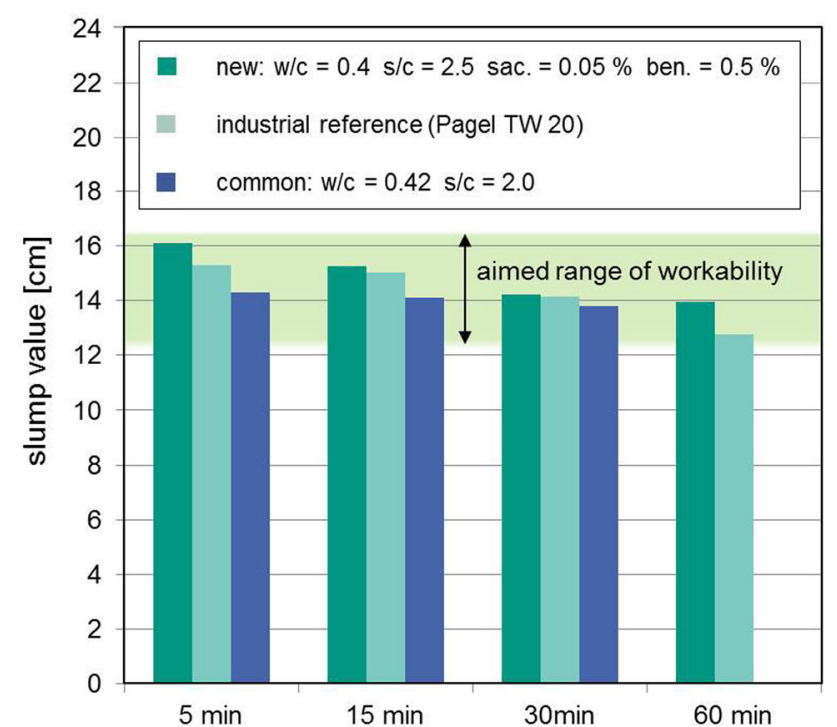

Fig. 9 Slump value over the processing period for the new mixture compared to an industrial reference (Pagel TW 20) and the common mixture in Indonesia

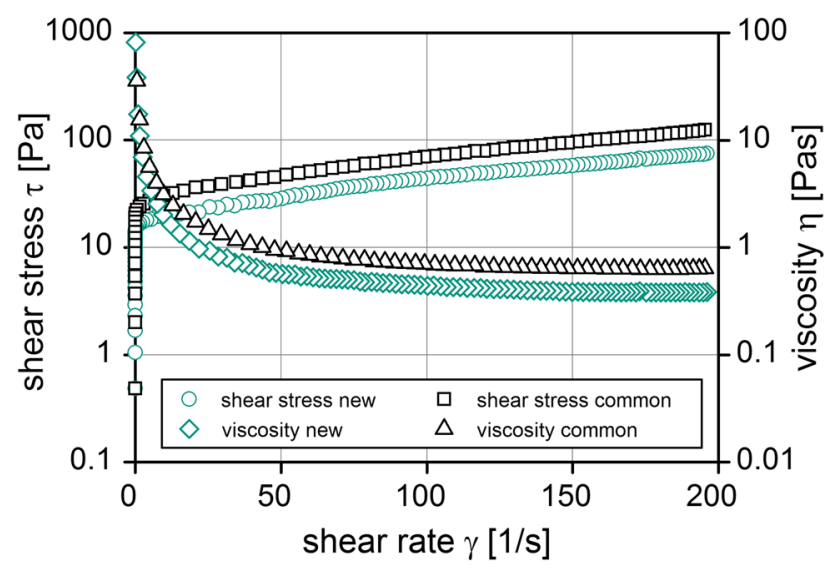

Fig. 10 Shear stress and viscosity over the shear rate of the new mixture (green) and the common mixture (black)

tendencies. Mixture Ref 2 showed higher porosities than the optimised mixtures $M 1-M 3$. However, mixture Ref 1 had a lower porosity in this case, which must be attributed to its unknown mixture composition. It could be possible that further chemical agents are admixed to enhance the sealing behaviour.

\section{Discussion}

Rehabilitation mortars may include, besides the main ingredients cement, sand and water, various organic or mineral additions, which influence the mortar properties. As commercially available additions are quite expensive
Table 2 Mix design and main rheological properties of the new and the common mortar

\begin{tabular}{lll}
\hline Parameter & New & Common \\
\hline Cement & $634 \mathrm{~kg} / \mathrm{m}^{3}$ & $698 \mathrm{~kg} / \mathrm{m}^{3}$ \\
Water & $254 \mathrm{~kg} / \mathrm{m}^{3}$ & $314 \mathrm{~kg} / \mathrm{m}^{3}$ \\
Sand & $1355 \mathrm{~kg} / \mathrm{m}^{3}$ & $1262 \mathrm{~kg} / \mathrm{m}^{3}$ \\
$w / c$-ratio & 0.4 & 0.45 \\
$s / c$-ratio & 2.5 & 2.0 \\
Saccharose & $0.05 \%$ & - \\
Bentonite & $0.5 \%$ & - \\
Yield stress & $17 \mathrm{~Pa}$ & $19 \mathrm{~Pa}$ \\
Viscosity & $0.38 \mathrm{~Pa} \mathrm{~s}$ & $0.65 \mathrm{~Pa} \mathrm{~s}$ \\
\hline
\end{tabular}

and hardly available in the remote region of Gunung Kidul, alternative additives and admixtures were chosen to be examined. The main focus in this regard was on the investigation of local retail sugar as an alternative for liquefying additives. Furthermore, bentonite was tested as an alternative for commercial stabilisers. Moreover, an Indonesian rice husk ash (abu sekam padi) was treated with different methods and the influence on the puzzolanic reaction was determined.

Starting with a sand/cement-ratio of 2.0, the sand content of the rehabilitation mortar was increased to minimise the costs as well as the shrinkage tendency. At the same time, the water/cement-ratio was reduced as low as possible to enhance the durability of the construction material. This resulted logically in a clear deterioration of the mortar workability which was balanced with the addition of sugar in a dosage of $0.05 \%$ by mass of the cement. Negative effects were detected neither on the strength values of the mortar nor on its porosity.

The usage of stabilisers to prevent a bleeding of the mortars was not mandatory due to the low water content of the mortars. However, the objective was rather to enhance the applicability ("stickiness") of the mortar with higher sand content with cost-effective measures. The use of cassava flour as organic substance in the rehabilitation mortar was excluded also because of its high price. The clay mineral bentonite was investigated in detail and finally added to the mortar in a dosage of $0.5 \%$ by mass of the cement. Although it resulted in a slight reduction of the workability, the applicability was positively influenced.

The usage of rice husk in the rehabilitation mortar was abandoned, as it reduced the workability notably while its beneficial effect on the puzzolanic reaction could not be proven clearly within this study.

The optimal mixture regarding a favourable compromise of fresh and hardened mortar properties was achieved with a mixture containing a water/cement-ratio of 0.4 , a sand/ cement-ratio of 2.5 and both saccharose with a content of 
Table 3 Mix compositions for the investigations of the hardened mortar properties

\begin{tabular}{|c|c|c|c|c|}
\hline \multirow[t]{2}{*}{ Name } & \multirow[t]{2}{*}{$w / c(-)$} & \multirow[t]{2}{*}{$s / c(-)$} & \multicolumn{2}{|c|}{ (\% by mass of cement) } \\
\hline & & & sac. & rha./ben. \\
\hline Ref 1 & \multicolumn{4}{|c|}{ Industrial reference (Pagel TW 20) } \\
\hline $\operatorname{Ref} 2$ & 0.45 & 2.0 & - & - \\
\hline$M 1$ & 0.4 & 2.5 & - & - \\
\hline$M 2$ & 0.4 & 2.5 & 0.05 & - \\
\hline M3 & 0.4 & 2.5 & 0.05 & 0.5 ben. \\
\hline
\end{tabular}

Table 4 Results of the investigations on the hardened mortars

\begin{tabular}{|c|c|c|c|c|}
\hline Name & $f_{\mathrm{cm}}(\mathrm{MPa})$ & $f_{\mathrm{ct}, \mathrm{fl}}(\mathrm{MPa})$ & Density $\left(\mathrm{g} / \mathrm{cm}^{3}\right)$ & $\mathrm{Hg}$-porosity $(\%)$ \\
\hline Ref 1 & 69.4 & 9.3 & 2.3 & 17.2 \\
\hline Ref 2 & 80.3 & 12.0 & 2.6 & 16.3 \\
\hline$M 1$ & 73.0 & 11.2 & 2.5 & 12.7 \\
\hline$M 2$ & 74.8 & 10.6 & 2.5 & 13.8 \\
\hline M3 & 71.6 & 10.4 & 2.5 & 13.6 \\
\hline \multirow[t]{2}{*}{ Name } & \multicolumn{2}{|c|}{ Water absorption (\%) } & & Total porosity (\%) \\
\hline & $1 \mathrm{bar}$ & 150 bar & $1 \mathrm{bar}$ & 150 bar \\
\hline Ref 1 & 7.9 & 8.5 & 15.7 & 16.8 \\
\hline Ref 2 & 9.2 & 10.8 & 19.5 & 23.0 \\
\hline$M 1$ & 7.9 & 9.4 & 16.9 & 20.0 \\
\hline$M 2$ & 8.2 & 9.8 & 17.4 & 20.7 \\
\hline M3 & 8.4 & 10.1 & 17.6 & 21.4 \\
\hline
\end{tabular}

Fig. 11 Pore size distribution of all mixtures

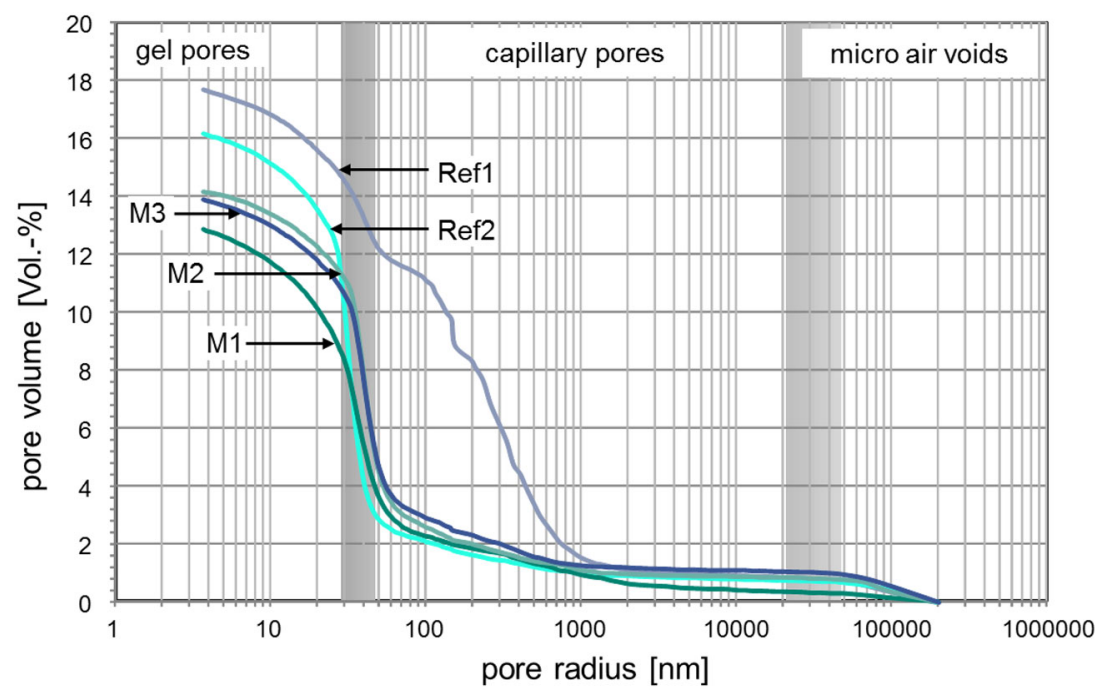

$0.05 \%$ and bentonite with $0.5 \%$ by mass of the cement. It shows a high strength and a low porosity with only a small share of capillary pores. By increasing the sand content, the higher cement content due to the lower water/cement-ratio was compensated. Compared to the Indonesian reference mixture, even a reduction of the cement content of $10 \%$ was achieved while maintaining the known workability.
This means that the former size of the cisterns of $9 \mathrm{~m}^{3}$ could be enlarged to $10 \mathrm{~m}^{3}$ while keeping the material costs constant.

As stated before, it became evident during the construction works, that from a technical and economical point of view, the in-situ rheological behaviour of the mortar is the key factor to achieve the best possible tightness of 


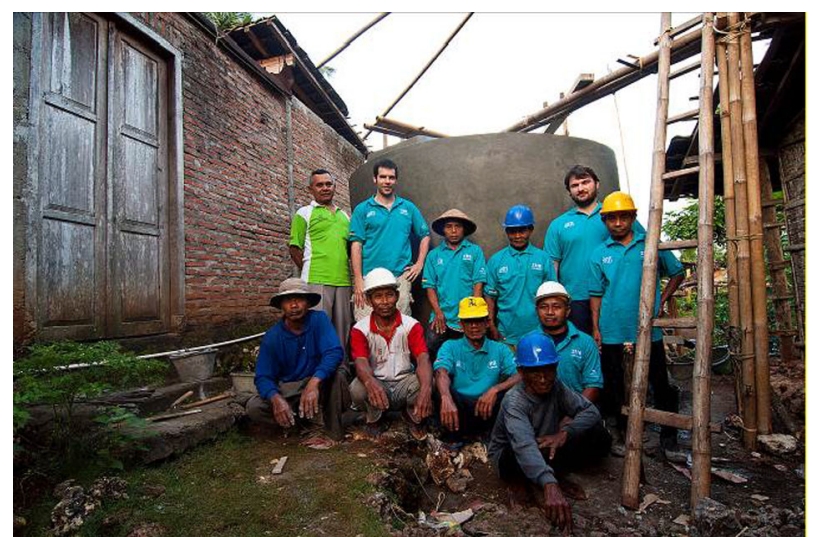

Fig. 12 Group picture after finishing of the cistern construction using the developed material concept

water cisterns. Therefore, the methodology of how to compose the mortar according to its intended range of application was summarised in a comprehensible practical guideline.

It was translated (German-English-Indonesian) and handed over to the villagers as an important part of the capacity development. The basic concept was already discussed in detail and field-tested with the local persons being responsible for construction activities during preceding stays in Pucanganom. The joint construction of a complete new cistern in September 2012 revealed a valuable knowledge regarding the construction procedure and the behaviour of the developed material in-situ (see Figs. 2, $3,4)$. It was used to further adapt the developed concept to the local situation. The revised concept including the finally developed material composition was successfully implemented with the joint construction of two further cisterns in May 2013 (see Fig. 12) and September 2014.

\section{Conclusions and outlook}

By means of a case study, the successful development and implementation of a rheologically optimised cement-based mortar for the appropriate construction as well as rehabilitation of rain water cisterns in Indonesia is presented in this paper. In the process the effects of different source materials on the rheological properties of pure cement suspensions were examined while the actual workability of the hydraulic materials was verified with fresh mortar experiments. Finally the mechanical properties were determined on hardened mortar specimens.

The developed material can be used as a coating for walls, floors and ceilings of cisterns, for the local rehabilitation of damaged areas only or even as a construction material for complete new cisterns. For the selection of the source materials, special emphasis was placed on a ready availability and low costs. The rheological properties of the fresh mortar allow an easy workability by hand while the hardened mortar shows a durable and tight appearance at the same time.

During March and September 2014, tightness and serviceability of the cisterns build up to that point were examined during field investigations and discussions with the local users. It was apparent, that, due to the close cooperation with the local persons being responsible for construction activities, the concept for cistern construction was very well accepted by the inhabitants of the village.

Due to the positive feedback, the construction of further cisterns was planned by the villagers. However, in this case, only a consulting support can be foreseen, which should on the one hand encourage the personal responsibility of the local population. On the other hand, it will be subject to verification to what extent the concept is really adopted and continued independently in the future without the support of the IWRM network.

Acknowledgments The financial support by the German Federal Ministry of Education and Research (BMBF) under the Grant No. 02WM0881 is gratefully acknowledged by the authors.

Open Access This article is distributed under the terms of the Creative Commons Attribution 4.0 International License (http:// creativecommons.org/licenses/by/4.0/), which permits unrestricted use, distribution, and reproduction in any medium, provided you give appropriate credit to the original author(s) and the source, provide a link to the Creative Commons license, and indicate if changes were made.

\section{References}

Bohner E, Fenchel M, Müller HS (2009) Konzeption und Herstellung eines unterirdischen Betonsperrwerks zur Trinkwassergewinnung auf Java. WasserWirtschaft 99(7/8):47-52

DIN 52009 (2006) Prüfverfahren für Gesteinskörnungen-Bestimmung der Wasseraufnahme unter Druck. Beuth, Berlin

DIN 52102 (2006) Prüfverfahren für Gesteinskörnungen-Bestimmung der Trockenrohdichte mit dem Messzylinderverfahren und Berechnung des Dichtigkeitsgrades. Beuth, Berlin

DIN 66133 (1993) Bestimmung der Porenvolumenverteilung und der spezifischen Oberfläche von Feststoffen durch Quecksilberintrusion. Beuth, Berlin

DIN EN 1015-11 (2007) Bestimmung der Biegezug- und Druckfestigkeit von Festmörtel. Beuth, Berlin

DIN EN 1015-11 (2009) Prüfung von Festbeton-Teil 7: Dichte von Festbeton. Beuth, Berlin

DIN EN 1015-3 (2007) Bestimmung der Konsistenz von Frischmörtel (mit Ausbreittisch). Beuth, Berlin

DVGW Arbeitsblatt W 300 (2005) Technische Regel, Wasserspeicherung-Planung, Bau, Betrieb und Instandhaltung von Wasserbehältern in der Trinkwasserversorgung. Deutscher Verein des Gas- und Wasserfaches e.V., Bonn

Haist M (2009) Zur Rheologie und den physikalischen Wechselwirkungen bei Zementsuspensionen. Dissertation, Institute of 
Concrete Structures and Building Materials, Karlsruhe Institute of Technology, Karlsruhe

Heid T (2012) Mörtelentwicklung zur angepassten Instandsetzung von Wasserspeichern in Indonesien. Diploma thesis, Institute of Concrete Structures and Building Materials, Karlsruhe Institute of Technology, Karlsruhe

Institute of Concrete Structures and Building Materials (IMB), Department Building Materials (2002) Konstruktionsbericht. Ansoreni. Karlsruhe Institute of Technology (KIT), Karlsruhe

Müller HS, Fenchel M, Bohner E, Mutschler T (2008) Bau eines Höhlenkraftwerkes zur Trinkwassergewinnung auf Java, Teil 2: Konzeption und Realisierung des Sperrwerkes unter Berücksichtigung örtlich verfügbarer Baustoffe und Technologien. In: Müller HS, Nolting U, Haist M (eds) Symposium Baustoffe und Bauwerkserhaltung. University of Karlsruhe Scientific Publishing, Karlsruhe, pp 121-137

Nestmann F, Oberle P, Ikhwan M, Stoffel D (2012) Experiences concerning the implementation of innovative technologies and management strategies in emerging countries: example IWRM Indonesia. In: Proceedings of the IWRM Karlsruhe 2012, Karlsruhe, pp 41-53

Nestmann F, Oberle P, Ikhwan M, Stoffel D, Blaß HJ, Töws D, Schmidt S (2015) Transfer of adapted water supply technologies through a demonstration and teaching facility. Submitted for publication to "Applied Water Science"

Oberle P, Kappler J, Unger B (2005) Integriertes WasserressourcenManagement (IWRM) in Gunung Kidul, Java, Indonesien. Schlussbericht zur Machbarkeitsuntersuchung im Auftrag des $\mathrm{BMBF}$. Institut für Wasser und Gewässerentwicklung, University of Karlsruhe, Germany

Walter TR et al (2008) The 26 May 2006 magnitude 6.4 Yogyakarta earthquake south of Mt. Merapi volcano: did lahar deposits amplify ground shaking and thus lead to the disaster? G3 Geochem Geophys Geosyst 9(5):1-9 